\title{
The carboxyl terminus of VEGF-A is a potential target for anti-angiogenic therapy
}

\author{
James G. Carter • Melissa V. R. Gammons • \\ Gopinath Damodaran • Amanda J. Churchill • \\ Steven J. Harper · David O. Bates
}

Received: 22 April 2014/ Accepted: 10 September 2014/Published online: 2 October 2014

(C) The Author(s) 2014. This article is published with open access at Springerlink.com

\begin{abstract}
Anti-VEGF-A therapy has become a mainstay of treatment for ocular neovascularisation and in cancer; however, their effectiveness is not universal, in some cases only benefiting a minority of patients. Anti-VEGF-A therapies bind and block both pro-angiogenic VEGF- $\mathrm{A}_{\mathrm{xxx}}$ and the partial agonist VEGF- $\mathrm{A}_{\mathrm{xxx}} \mathrm{b}$ isoforms, but their anti-angiogenic benefit only comes about from targeting the pro-angiogenic isoforms. Therefore, antibodies that exclusively target the pro-angiogenic isoforms may be more effective. To determine whether C-terminal-targeted antibodies could inhibit angiogenesis, we generated a polyclonal antibody to the last nine amino acids of VEGF$\mathrm{A}_{165}$ and tested it in vitro and in vivo. The exon8a polyclonal antibody (Exon8apab) did not bind VEGF- $\mathrm{A}_{165} \mathrm{~b}$ even at greater than 100-fold excess concentration, and dose dependently inhibited VEGF- $\mathrm{A}_{165}$ induced endothelial migration in vitro at concentrations similar to the VEGF-A antibody fragment ranibizumab. Exon8apab can inhibit tumour growth of LS174t cells implanted in vivo and blood vessel growth in the eye in models of age-related
\end{abstract}

James G. Carter and Melissa V. R. Gammons have contributed equally to this work.

J. G. Carter · M. V. R. Gammons · G. Damodaran ·

A. J. Churchill - S. J. Harper - D. O. Bates

Microvascular Research Laboratories, School of Physiology and Pharmacology, University of Bristol, Preclinical Veterinary

Sciences Building, Southwell Street, Bristol BS2 8EJ, UK

J. G. Carter · D. O. Bates $(\bowtie)$

Cancer Biology, Queens Medical Centre, University of Nottingham, D Floor West Block, Nottingham NG7 2UH, UK

e-mail: david.bates@nottingham.ac.uk macular degeneration, with equal efficacy to non-selective anti-VEGF-A antibodies. It also showed that it was the VEGF- $A_{x x x}$ levels specifically that were upregulated in plasma from patients with proliferative diabetic retinopathy. These results suggest that VEGF- $\mathrm{A}_{165}$-specific antibodies can be therapeutically useful.

Keywords VEGF · Splicing - Bevacizumab . VEGF- $\mathrm{A}_{165} \mathrm{~b}$

\section{Introduction}

Angiogenesis is implicated in the pathology of a range of diseases with a vascular element and as a key mediator of blood vessel growth, vascular endothelial growth factor (VEGF) has been extensively studied as a critical protein in pathological neovascularisation [8]. In 2002, the VEGF-A isoform family VEGF- $\mathrm{A}_{\mathrm{xxx}} \mathrm{b}$ was discovered and found to possess significant anti-angiogenic properties [3, 25]. These VEGF- $\mathrm{A}_{\mathrm{xxx}} \mathrm{b}$ isoforms can be distinguished from the pro-angiogenic VEGF-A isoforms (VEGF- $A_{x x x}$ ) by their terminal exon selection. Proximal splice site selection in the terminal exon, exon8a, encodes the terminal six amino acid sequence of CDKPRR to create the VEGF- $\mathrm{A}_{\mathrm{xxx}}$ isoforms, whereas distal splice site selection (exon8b, 66 bp $3^{\prime}$ from exon8a) creates the anti-angiogenic VEGF- $\mathrm{A}_{\mathrm{xxx}} \mathrm{b}$ isoforms with an altered 6 terminal amino acid sequence; SLTRKD [13].

Analysis of expression of VEGF- $A_{x x x} b$ isoforms shows they form a significant proportion of VEGF-A in most normal, non-angiogenic tissues such as dorsal root ganglia (71\%), lung (82\%) [3], skin (>95\%) [7], prostate [25], colon (>95\%) [24] and vitreous $(66 \%)$ [16], but it is a small proportion of the total VEGF-A concentration in 
angiogenic tissues such as placenta (1.4\%) [4]. Unlike conventional VEGF-A isoforms, VEGF- $\mathrm{A}_{165} \mathrm{~b}$ is downregulated in retinopathy and cancers such as renal cell carcinoma, [3] colon carcinoma [24], prostate carcinoma [25] and malignant melanoma [18].

Furthermore, VEGF- $\mathrm{A}_{165} \mathrm{~b}$ expression inhibits VEGF$\mathrm{A}_{165}$-mediated proliferation, migration and vasodilation in vitro $[3,20,21]$ as well as in vivo models of angiogenesis including rat mesentery and rabbit cornea [25], mouse skin and chick chorioallantoic membrane [23], Matrigel implants [10], rat mammary gland [19], rat ovary [1] and tumour models [21, 24].

The ability to detect VEGF-A in biological samples is critical for the assessment of angiogenesis and commercial panVEGF-A ELISA kits are widely available, with the R\&D Systems ELISA (DY293B, R\&D Systems) one of the most commonly cited. A method for VEGF- $A_{x x x} b$ isoform detection in both laboratory and medical samples has already been established [6, 16, 25] and a commercial version has been available for several years (DY3045, R\&D Systems). However, similar products to specifically detect VEGF- $\mathrm{A}_{\mathrm{xxx}}$ isoforms, as opposed to pan VEGF, are still relatively scarce. Thus, despite the important physiological role that the balance of VEGF-A $\mathrm{Axx}_{\mathrm{xx}}$ and VEGF$\mathrm{A}_{\mathrm{xxx}} \mathrm{b}$ isoforms has in angiogenesis, the ability to distinguish between each isoform family is severely limited experimentally.

The lack of reliable assays is partly due to the success of anti-VEGF-A therapies that bind both VEGF- $\mathrm{A}_{\mathrm{xxx}}$ and VEGF- $A_{x x x} b$ isoforms that, at first glance, do not require a distinction between isoforms. The application of such nonspecific therapeutics has been shown to be clinically successful in the treatment of colorectal carcinoma (e.g. bevacizumab, Avastin ${ }^{\circledR}$ ) [9] and age-related macular degeneration (AMD, e.g. ranibizumab, Lucentis ${ }^{\circledR}$ ) [11]. However, the application of anti-panVEGF-A therapeutics has no effect on a sub-population of patients [9]. A recent study in metastatic colorectal carcinoma patients showed that only those patients with low VEGF-A $\mathrm{Axx}_{\mathrm{xx}} \mathrm{b}: \mathrm{VEGF}_{\text {total }}$ isoform ratios respond positively to bevacizumab therapy, whilst those with a higher relative expression of VEGF$\mathrm{A}_{\mathrm{xxx}} \mathrm{b}$ isoforms do not benefit from anti-VEGF-A therapy [2]. Thus, the targeted inhibition of the pro-angiogenic VEGF- $A_{x x x}$ isoforms without the loss of VEGF- $A_{x x x} b$ isoforms is a more attractive therapy; inhibiting pathological angiogenesis without the loss of cytoprotective VEGF$\mathrm{A}_{\mathrm{xxx}} \mathrm{b}$ required to maintain a healthy vasculature.

Here, we present data to show that targeted inhibition of VEGF-A $_{\mathrm{xxx}}$ isoforms with Exon8apab, a polyclonal antibody specific to the exon8a (CDKPRR) amino acid sequence, is as effective as current anti-panVEGF-A therapeutics but may be more physiologically applicable in the treatment of VEGF-mediated pathologies.

\section{Methods}

Anti-VEGF- $\mathrm{A}_{165}$ a antibody

Rabbits were immunized with a nine amino acid peptide encoded by the C-terminal of VEGF-A A $_{165}$ TCRCDKPRR - conjugated to KLH by Abgent Inc. Plasma was taken and screened for VEGF- $\mathrm{A}_{165}$-specific activity. One rabbit generated specific polyclonal antibodies. Plasma was taken from this rabbit on at least three occasions and activity confirmed. A final bleed was then subjected to immunopurification by standard methodology.

\section{Cell migration assay}

Human umbilical vein endothelial cells (HUVECs) were isolated as previously described and serum starved in endothelial basal media (EBM) for $12 \mathrm{~h}$. Cells were trypsinized and re-suspended in 0.1 \% FBS in EBM and 50,000 cells in $500 \mu \mathrm{l}$ medium were seeded on attachment factor (Cascade Biologics, Portland, OR, USA) coated filter inserts $(8 \mu \mathrm{m}$ pore, $12 \mathrm{~mm}$ diameter, Millipore, Billerica, MA, USA) with the treatment (1nM VEGF- $\mathrm{A}_{165} \mathrm{a}$, with or without VEGF-A antibody, or $10 \%$ FCS as a positive control) in the bottom well. Each treatment was performed in triplicate. Cells were incubated at $37{ }^{\circ} \mathrm{C}$ over night. Inserts were washed with PBS and cells fixed with $4 \%$ PFA/PBS pH 7.4 for $10 \mathrm{~min}$. The top of the membrane was carefully cleaned with a sterile cotton bud, the membrane stained with Hoechst $33258(5 \mu \mathrm{g} / \mathrm{ml}$ in $0.5 \%$ Triton/ PBS). Membranes were excised mounted bottom side up on microscope slides with Vectashield (Vetorlabs, Burlingame, CA, USA). Cells were counted in 10 randomly chosen fields away from the edge under a fluorescence microscope (Nikon Eclipse T200). Cell migration was expressed as the number of cells per high power field. The inhibitory effect on migration of VEGF-A antibodies was determined by increasing concentrations of antibody with $1 \mathrm{nM}(40 \mathrm{ng} / \mathrm{ml})$ VEGF-A 165 . IC I0 $_{50}$ was calculated from the normalised data using a variable slope sigmoidal fit (Prism4 software).

Laser-induced choroidal neovascularisation

Six- to eight-week-old C57/B6 mice (B\&K Laboratories) were anaesthetised with an intraperitoneal injection of a mixture of $50 \mathrm{mg} / \mathrm{kg}$ ketamine and $0.5 \mathrm{mg} / \mathrm{kg}$ medetomidine. The pupils were dilated with $2.5 \%$ phenylephrine hydrochloride and $1 \%$ tropicamide. Four photocoagulation lesions were delivered with a krypton red laser (mice: $250 \mathrm{~mW}, 0.01 \mathrm{~s}, 75 \mu \mathrm{m}$, rats: $200 \mathrm{~mW}, 0.01 \mathrm{~s}, 75 \mu \mathrm{m}$, IRIS Medical $810 \mathrm{~nm}$ Oculight Slx laser) between the "large" retinal vessels in a peripapillary distribution at a 
distance of 1-2 optic disc diameters in each eye. Only laser lesions with a subretinal bubble at the time of treatment were included in the study. Immediately following laser photocoagulation, the animals received intravitreal injections of $500 \mathrm{ng}$ IgG in the control eye and $500 \mathrm{ng}$ antiVEGF-A (G6-31) or $500 \mathrm{ng}$ exon8a PAb in the treated eye (day 0 and day 7). Animals were culled on day 14 and eyes fixed, enucleated and choroids stained and examined.

\section{VEGF-A $A_{x x x}$-specific ELISA}

Immunoassay 96-well plates were coated with Exon8apab antibody $(25 \mu \mathrm{g} / \mathrm{ml}$ in $1 \times \mathrm{PBS}, 100 \mu \mathrm{l} /$ well $)$ and left overnight at room temperature. After washing in triplicate $\left(0.05 \%\right.$ Tween $^{\circledR}$ in $1 \times$ PBS, $200 \mu \mathrm{l} /$ well $)$, immunoassay plates were blocked (1\% Bovine Serum Albumin in $1 \times$ PBS, $200 \mu \mathrm{l} /$ well) and incubated at $37{ }^{\circ} \mathrm{C}$ for minimum of $2 \mathrm{~h}$. The plates were washed and samples added, using recombinant human VEGF-A 165 (840164, R\&D Systems) as a serial dilution control standard. Samples were assessed in triplicate $(100 \mu \mathrm{l} /$ well, diluted in $1 \% \mathrm{BSA} / \mathrm{PBS})$. The plate was then incubated at $37^{\circ} \mathrm{C}$ for $2 \mathrm{~h}$ with shaking.

Following washing, biotinylated goat anti-human panVEGF-A detection antibody (BAF293, R\&D Systems) was added at $100 \mathrm{ng} / \mathrm{ml}$ in $1 \%$ BSA/PBS (100 $\mu \mathrm{l} / \mathrm{well})$. The plates were then incubated once more at $37{ }^{\circ} \mathrm{C}$ for $2 \mathrm{~h}$. Following washing, HRP-conjugated streptavidin was added (1:200 in 1\%BSA/PBS, $100 \mu \mathrm{l} /$ well, 890803, R\&D Systems) and incubated without light exposure or agitation for $30 \mathrm{~min}$ at RT. The plates were washed once more, and HRP ELISA substrate $(100 \mu \mathrm{l} /$ well, DY999, R\&D Systems) was added before a final incubation without light exposure at RT for $15-30 \mathrm{~min}$. A stop solution ( $1 \mathrm{M} \mathrm{H}_{2} \mathrm{SO}_{4}, 50 \mu \mathrm{l} /$ well) was then added directly to the substrate and resultant colour change measured at $450 \mathrm{~nm}$ using an Opsys MR plate reader (Dynex, USA).

\section{Plasma extraction and analysis}

Patients were recruited from the vitrectomy clinics from the Bristol Eye Hospital. All study participants were Caucasians of Northern European origin. Ethics approval for the study was obtained from the North Somerset and South Bristol Research Ethics Committee and protocols conformed to the tenets of the Declaration of Helsinki, as revised in 2000. A venous blood sample was obtained from each participant after informed written consent. Patient samples were divided by diabetic status into three subgroups; proliferative diabetic retinopathy (PDR group, $n=8$ ), patients with non-proliferative diabetic retinopathy (NPDR group, $n=11$ ) and patients without diabetes (nondiabetic/ND group, $n=22$ ). Peripheral blood plasma was separated by centrifugation $(15 \mathrm{~min}$ at $2,000 \times g)$ and aliquoted into individual vials (100-200 $\mu \mathrm{l})$ for storage at $-80{ }^{\circ} \mathrm{C}$ prior to the study. Assessment of VEGF-A $\mathrm{Axx}_{\mathrm{xx}} \mathrm{a}$ isoform concentrations were determined using the ELISA

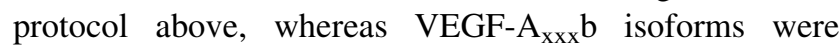
assessed by ELISA as described in [6].

Tumour growth assays

$2 \times 10^{6}$ LS174t colon cancer cells were prepared after trypsinisation in $0.2 \mathrm{ml} \mathrm{PBS}$ and injected subcutaneously in the dorsum of 6 nude Balb/C mice for each group. The mice were monitored bi-weekly for tumour development. Once tumours had developed mice were randomly allocated to each of three groups and injected i.p. with either $50 \mu \mathrm{g}$ bevacizumab, Exon8apab or mouse IgG in $100 \mu \mathrm{l}$ saline, coded and blinded for the injector and measurer. Tumours were measured 3 days later and injected with a second dose of the antibody. Animals were killed 7 days later, because insufficient Exon8apab antibody was available for further treatment.

\section{Results}

Exon8apab is selective for VEGF-A 165 over VEGF$\mathrm{A}_{165} \mathrm{~b}$

Specificity of the antibody for the angiogenic phenotypes was determined by ELISA (Fig. 1a) and Western blot (Fig. 1b). Recombinant human VEGF-A 165 but not VEGF$\mathrm{A}_{165} \mathrm{~b}$ was detected by Exon8apab. The commercially available VEGF-A xxx $_{x}$ b-specific antibody MAB3045 (R\&D Systems) in the same assays detected VEGF-A $\mathrm{A}_{165}$ b but not VEGF-A 165 . Using Exon8apab as a capture antibody for VEGF-A protein in a sandwich ELISA assay showed detection above background at $62.5 \mathrm{pg} / \mathrm{ml}$ (similar to commercially available pan-VEGF-A antibodies), In contrast recombinant human VEGF-A $\mathrm{Axx}_{\mathrm{xx}} \mathrm{b}$ was not detected using Exon8apab even up to $2000 \mathrm{pg} / \mathrm{ml}$.

Exon8apab inhibits endothelial cell migration in response to $\mathrm{VEGF}-\mathrm{A}_{165}$

Treatment of HUVEC cells with VEGF-A ${ }_{165}$ resulted in a significant migration similar to that induced by $10 \%$ serum (Fig. 2a). This was dose dependently inhibited by treatment with Exon8apab $\left(\mathrm{IC}_{50}=0.115 \mathrm{nM} \quad 95 \% \quad \mathrm{CI}\right.$ 0.07-0.19, Fig. 2b). Comparison with ranibizumab demonstrated that the potency of the polyclonal antibody was greater, but not statistically significantly so than that of a panVEGF-A antibody $\left(\mathrm{IC}_{50}=0.228,95 \%\right.$ CI $0.17-0.311$, $p=0.059)$. 


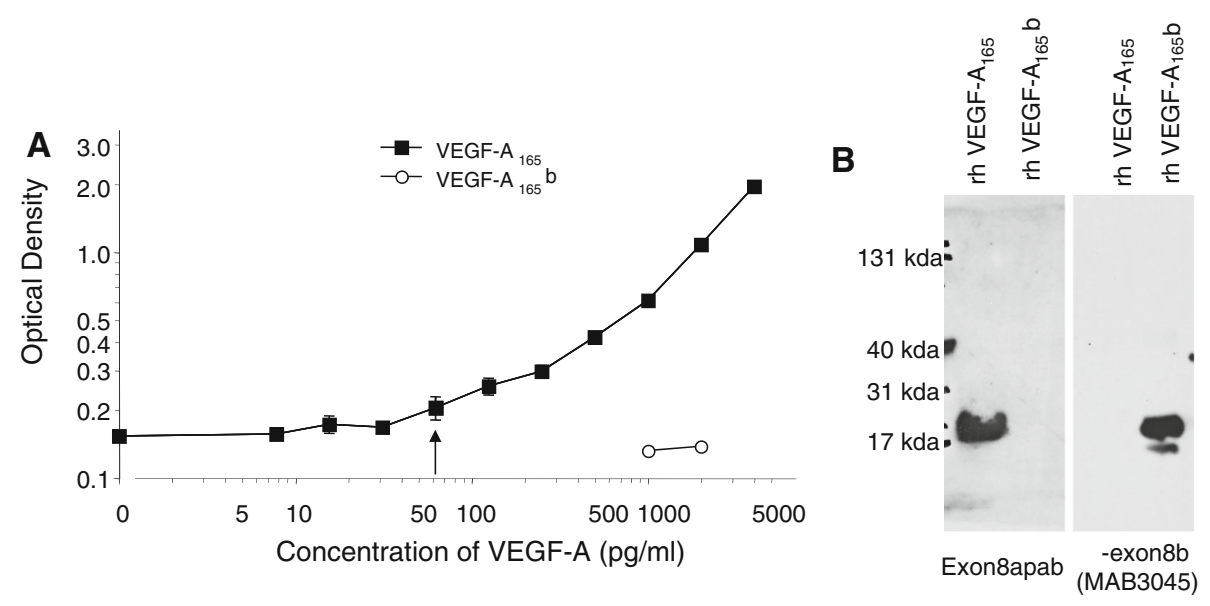

Fig. 1 Exon8apab is specific for VEGF-A ${ }_{165}$ a. a An ELISA with Exon8apab as a capture antibody and a biotinylated goat anti-human panVEGF-A detection antibody with increasing concentration of $\mathrm{VEGF}_{165} \mathrm{a}$ (closed circles) or $\mathrm{VEGF}_{165} \mathrm{~b}$ (open circles) was carried out. b Western blot using the two antibodies demonstrated specificity of the Exon8apab for $20 \mathrm{ng}$ recombinant human VEGF-A ${ }_{165}$ a and a monoclonal antibody to the $\mathrm{c}$ terminus of rhVEGF-A $\mathrm{A}_{165} \mathrm{~b}$ for $20 \mathrm{ng}$ of VEGF- $A_{165} b$. Neither antibody recognised the other protein
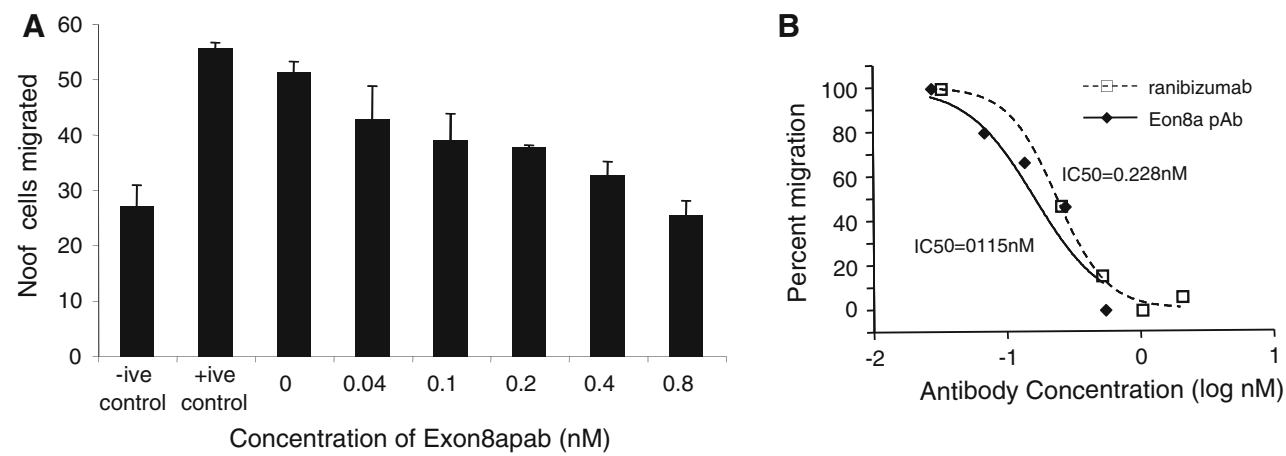

Concentration of Exon8apab (nM)

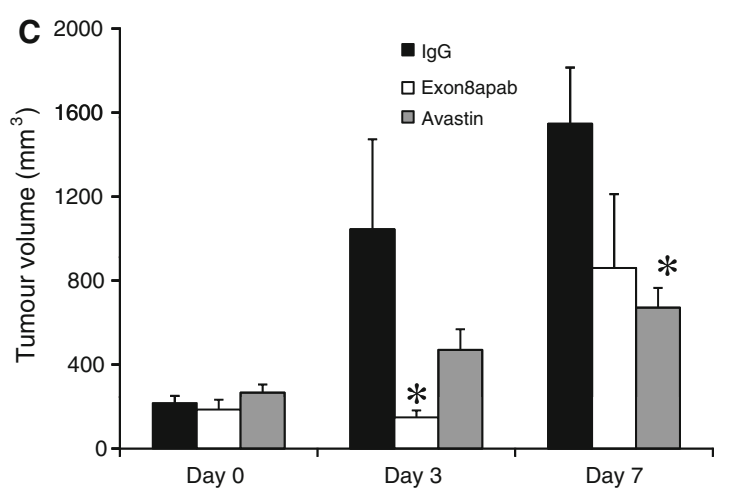

Fig. 2 Exon8apab inhibits angiogenesis. a Endothelial cells were seeded onto polycarbonate filters of transwell inserts. Increasing concentrations of Exon8apab and $40 \mathrm{ng} / \mathrm{ml}$ rhVEGF-A ${ }_{165}$ a was added to the lower well. Cell migration across was measured by counting cells on the lower side of the membrane $24 \mathrm{~h}$ after seeding. b The experiment was repeated using either Exon8apab or ranibizumab.

Exon8apab slows tumour growth similarly to antiVEGF-A antibodies

To determine whether the antibody could inhibit tumour growth, we treated LS174t heterotopic colon cancer
$\mathrm{IC}_{50}$ was calculated using a variable slope dose inhibition curve (Prism4.0). c LS174t cells $\left(1 \times 10^{9}\right)$ were implanted into nude mice and tumours allowed to grow to approximately $200 \mathrm{~mm}^{3}$. Animals were then treated with $2 \mathrm{mg} / \mathrm{kg}$ Exon8apab antibody at D0 and treatment repeated at D3. Tumour volumes were measured once more at D7. $* p<0.05$, one-way ANOVA, Bonferroni test

tumour bearing mice with bevacizumab or anti-VEGF$\mathrm{A}_{165}$ Exon8apab ( $n=6$ per group). Tumours were not different in size after 1 week of implantation due to matched allocation to treatment group. Three days after initial treatment Exon8apab treated tumours were 


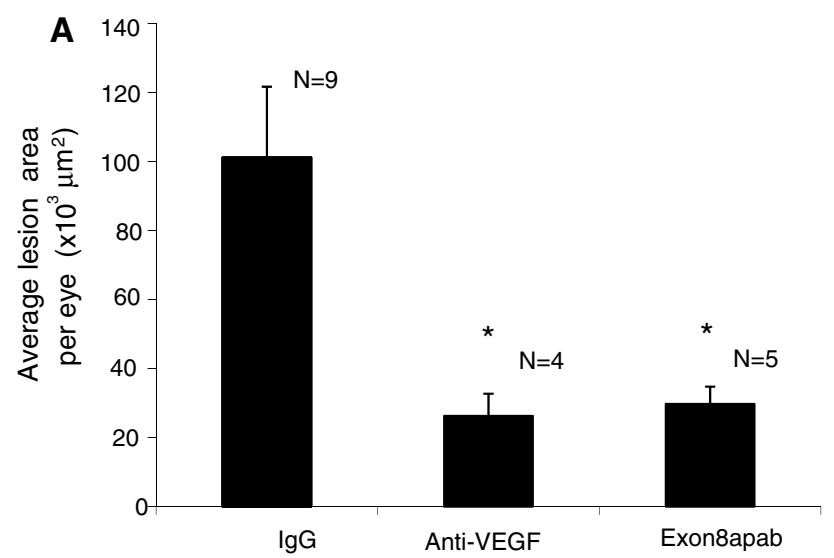

B
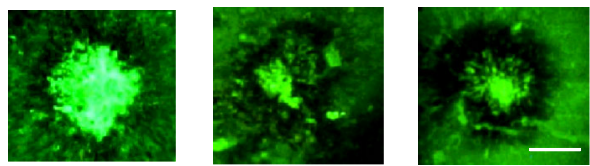

Fig. 3 Exon8apab inhibits laser-induced CNV in mice. C57/B6 mice underwent retinal lasercoagulation in both eyes (IRIDEX Oculight GLX $\lambda-810 \mathrm{~nm}, 250 \mathrm{mV}, 0.1 \mathrm{~s}, 75 \mu \mathrm{m}, 4$ lesions/eye). Animals were subjected to intraocular injection with either $500 \mathrm{ng}(250 \mathrm{ng} / \mu \mathrm{l})$ of an anti-mouse VEGF neutralising antibody, and control eyes injected with either mouse IgG, or $500 \mathrm{ng}(250 \mathrm{ng} / \mu \mathrm{l})$ of Exon8apab with a control rabbit $\operatorname{IgG}$ - controls administered at the same concentration, directly after laser procedure (D0) and on day 7. Staining with isolectin-B4 of the RPE-choroid-sclera complex showed a decrease in lesion size for anti-VEGF and Exon8apab $(N$, number of eyes; $* p<0.05$, one-way ANOVA, Bonferroni post hoc). Merged lesions were excluded from the study. Scale bar $50 \mu \mathrm{m}$

significantly smaller than IgG treated tumours (Fig. 2c). After 7 days, tumours from bevacizumab-treated mice groups were smaller than the $\operatorname{IgG}$ controls, $(p<0.05$, one-way ANOVA). Whilst 5/6 mice treated with Exon8apab showed tumours comparable with the bevacizumab treatment group, the remaining tumour grew significantly in those 4 days. As a result, whilst mean tumour volume was comparable with bevacizumab, there were no statistically significant differences between exon8apab treatment and IgG controls at Day 7.

\section{Exon8apab inhibited choroidal neovascularisation}

As the tumour studies required substantial amounts of the antibody, we used a laser-induced choroidal neovascularisation (CNV) assay to determine the anti-angiogenic activity of Exon8apab. In this model of angiogenesis, intraocular treatment with Exon8apab $(250 \mathrm{ng} / \mu \mathrm{l})$ had similar inhibitory effects to an anti-mouse VEGF-A antibody $(250 \mathrm{ng} / \mu \mathrm{l})$, with reduced lesion size at 7 days postphotocoagulation ( $p<0.05$, one-way ANOVA, Bonferroni post hoc) (Fig. 3).
Exon8apab detects circulating VEGF- $\mathrm{A}_{165} \mathrm{a}$

We used Exon8apab to detect circulating VEGF-A levels in plasma from patients with diabetes. Non-diabetic patients (ND), patients with non-proliferative diabetic retinopathy (NPDR) and proliferative diabetic retinopathy patients (PDR) had their venous blood plasma assessed for VEGF- $A_{x x x} b$ using an ELISA method adapted from [6] and VEGF-A $_{\mathrm{xxx}}$ using Exon8apab. Of the 45 patients from which plasma was collected VEGF levels were undetectable $(<15 \mathrm{pg} / \mathrm{ml})$ in 7 . The remaining $83 \%$ of patients had plasma levels detected by either VEGF- $\mathrm{A}_{165} \mathrm{~b}$ alone (2 patients), or both isoforms (32 patients).

Assessment of VEGF-A concentrations in plasma showed no statistically significant differences between the different subgroups by VEGF- $A_{x x x}$ and VEGF- $A_{x x x} b$ assessment $(p>0.05, t$ test, Fig. $4 a)$. However, there did appear to be a trend with higher anti-angiogenic VEGF$A_{x x x} b$ in the ND/NPDR groups and higher pro-angiogenic VEGF-A $_{\mathrm{xxx}}$ in the PDR subgroup. When the proportion of VEGF-A isoforms to combined total (VEGF- $A_{x x x}+$ VEGF- $A_{x x x} b=V E G F_{\text {sum }}$ ) was calculated, there appears to be a consistent shift from VEGF- $A_{x x x} b$ predominating in non-diabetics in favour of pro-angiogenic VEGF- $\mathrm{A}_{\mathrm{xxx}}$ in the PDR group (Fig. $4 \mathrm{~b}, p=0.050$ chi-squared test for trend). Analysis within subgroups showed that non-diabetic patients have no difference in the proportion of VEGF$\mathrm{A}_{\mathrm{xxx}} \mathrm{b}$ (47.6 vs. $\left.52.4 \%\right)$. The non-proliferative diabetics appear to show an intermediary balance of VEGF-A $A_{x x x} b$ to VEGF-A $_{\mathrm{xxx}}(43.9$ vs. $56.1 \%)$, whereas in proliferative diabetic patients the majority of VEGF-A produced is VEGF-A $_{\mathrm{xxx}}\left(81.1\right.$ vs. $18.9 \%$ VEGF-A $\mathrm{x}_{\mathrm{xxx}} \mathrm{b}, p=<0.01$ one-way ANOVA, Bonferroni test.).

\section{Discussion}

Here, we show that an antibody directed against the $\mathrm{C}$ terminus of VEGF- $\mathrm{A}_{165}$ is able to inhibit VEGF- $\mathrm{A}_{165^{-}}$ mediated cell migration, angiogenesis and tumour growth in vivo and can be used to detect VEGF- $\mathrm{A}_{165}$ (but also presumably other VEGF- $\mathrm{A}_{\mathrm{xxx}}$ isoforms) in human plasma. The antibody generated was a polyclonal antibody from a single rabbit. We attempted during this project to generate monoclonal antibodies from mice both in house and commercially and failed on three occasions. Moreover, only one of six rabbits generated antibodies that were effective in detecting VEGF- $\mathrm{A}_{165}$. The supply of the antibody is therefore limited, and we surmise that antigenicity of the peptide is relatively low. Interestingly, there have only ever been two published antibodies against the $\mathrm{C}$ terminus of VEGF- $\mathrm{A}_{165} \mathrm{~b}$ - this one and the original VPF antibody generated by Donald Senger in 1986 [22]. Both are rabbit 


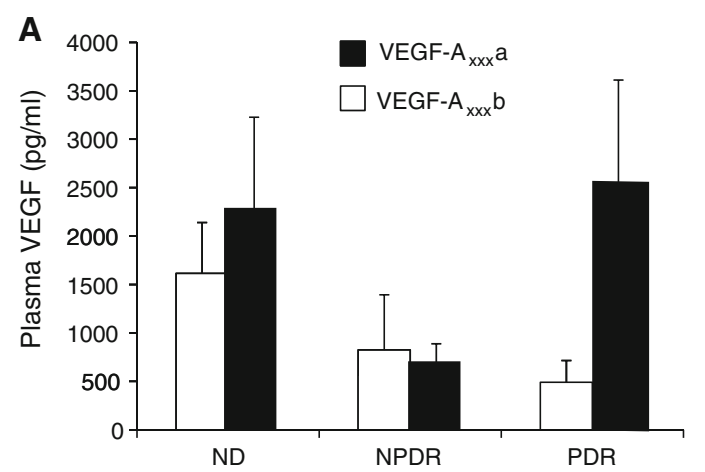

Fig. 4 Exon8apab measures VEGF levels in human plasma. VEGF levels were measured in plasma from 32 patients, 5 of whom had proliferative diabetic retinopathy (PDR), 11 non-proliferative diabetic retinopathy (NPDR) and 18 control patients with no diabetes (ND). a VEGF concentrations were measured by ELISA using either the

polyclonals, and all other VEGF antibodies commercially available, or available by collaboration have targeted either exons 3-4 or exon 6 [17]. It is therefore clear that generation of C-terminal antibodies is not widely in use, and we have not been able to generate specific antibodies with the efforts described here. For this reason, only a preliminary tumour study was carried out in mice, but the evidence we have suggests that $\mathrm{C}$-terminal antibodies targeting all VEGF- $A_{x x x}$ isoforms, when they can be generated, are at least as effective as receptor binding domain antibodies such as ranibizumab or bevacizumab at inhibiting VEGF$\mathrm{A}_{165}$.

These results raise a number of interesting questions. First, it shows that it is possible to generate antibodies that specifically target the pro-angiogenic isoforms of VEGF, without affecting the anti-angiogenic, cytoprotective isoforms such as VEGF- $\mathrm{A}_{165} \mathrm{~b}$. This would result in antibodies that do not suffer from the resistance associated with targeting all VEGF isoforms in colon cancer for instance [2]. It may also result in safer, more effective anti-VEGF-A therapies for eye disease, where long-term use of panVEGF-A antibodies are associated with progressive vision loss, possibly due to geographic atrophy [14].

These antibodies also raise the interesting likelihood that conventional assessment techniques for measuring circulating VEGF-A levels are inaccurate and could be replaced. There are several limitations to the application of these panVEGF-A assays. First, they are not applicable to all sample types. For example, competition for epitopes between antibodies and native molecules such as high concentrations of the proteinase inhibitor $\alpha_{2}$-macroglobin in human plasma are capable of binding VEGF-A and therefore reduces anti-VEGF-A antibody binding by $82 \%$ [5]. Secondly, the inability for panVEGF-A detection methods to distinguish between VEGF- $A_{\mathrm{xxx}}$ and VEGF$\mathrm{A}_{\mathrm{xxx}} \mathrm{b}$ isoforms means any alterations in splicing with

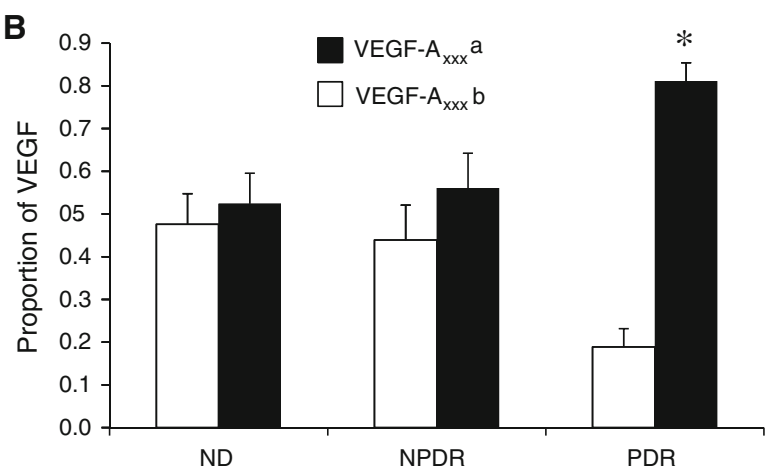

anti-VEGF- $\mathrm{A}_{165} \mathrm{~b}$ as a capture antibody, or exon8apab as a capture antibody. $\mathbf{b}$ The relative amount of the two isoforms was calculated as a per cent of the total-e.g. 100*VEGF-A $\mathrm{xxx}_{\mathrm{b}} \mathrm{b} /\left(\mathrm{VEGF}-\mathrm{A}_{\mathrm{xxx}-}\right.$ $\mathrm{a}+$ VEGF-A $\left.\mathrm{A}_{\mathrm{xxx}} \mathrm{b}\right) . \quad * p<0.05$ compared with VEGF-A $\mathrm{A}_{\mathrm{xxx}} \mathrm{b}$, Bonferroni

significant physiological implications will not be detected. Thirdly, such panVEGF-A antibodies have different affinities for the different isoform families. Assessment by both ELISA and surface plasmon resonance showed that the R\&D Systems DuoSet panVEGF-A antibody only detects $42 \pm 0.4 \%$ of VEGF- $A_{x x x} b$, due to a difference in binding affinity; $602 \mathrm{pM}$ for VEGF- $\mathrm{A}_{\mathrm{xxx}}$ versus $3.98 \mathrm{nM}$ for VEGF- $A_{x x x} b$, an $\sim 6.6$-fold difference in affinity [24]. The results of such assays mean that the circulating levels of VEGF-A found in normal plasma are regularly reported at variously between 0 and $200 \mathrm{pg} / \mathrm{ml}$, whereas early assays using enzyme immunoassays (EIA) or differential epitope antibodies put the concentration at $>1 \mathrm{ng} / \mathrm{ml}$. Here, we show that in normal control patients the total VEGF-A levels are around $4 \mathrm{ng} / \mathrm{ml}$, of which $1.5 \mathrm{ng} / \mathrm{ml}$ is VEGF$\mathrm{A}_{\mathrm{xxx}}$ and $2.5 \mathrm{ng} / \mathrm{ml}$ is VEGF- $\mathrm{A}_{165} \mathrm{~b}$. This fits with early methods, and with Western blots showing detectable levels of VEGF-A in plasma when concentrated 10× (unpublished data), suggesting that the original concentration of the order of $1-10 \mathrm{ng} / \mathrm{ml}(200 \mathrm{pg} / \mathrm{ml}$, even concentrated $10 \mathrm{x}$ would require $1 \mathrm{ml}$ of plasma to be loaded into a single well of a SDS PAGE gel).

The results also suggest that the C-terminal tail of VEGF- $A_{165}$ is required for VEGFR activation. However, crystallographic studies of VEGF-A have shown that it is the amino acids encoded by exons 3 and 4 , not exon 8 , that are the receptor binding domain [12]. Whilst the full length VEGF including the C-terminal tail has never been crystallised, and it has been shown that VEGF-A $\mathrm{A}_{159}$ (a protein missing the last six amino acids) is capable of both receptor binding and inducing angiogenesis [23]. Crucially, despite equal receptor binding affinity between VEGF-A $\mathrm{A}_{165}$,

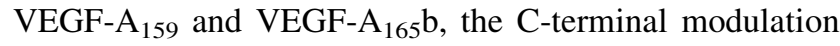
determines whether the response is angiogenic (receptor activation) or anti-angiogenic (inhibitory). If the last few (>6) amino acids of the protein were to be required to 
interact with the receptor binding domain then an antibody to the $\mathrm{C}$ terminus could disrupt that activation. In addition, recent studies of the VEGFR co-receptor neuropilin-1 (Nrp-1) have shown that the $\mathrm{C}$ terminus of VEGF-A $\mathrm{A}_{165}$, particularly Arg-164, mediates high affinity binding of Nrp-1, increasing VEGFR activity [15]. These results therefore suggest that the $\mathrm{C}$ terminus of the VEGF-A protein might be able to interact with the receptor binding domain, or at least be brought within its vicinity during receptor activation. Thus, the action of the Exon8apab antibody must be interfering with the $\mathrm{C}$ terminus-neuropilin/receptor binding domain interaction, presumably through disruption to stoichiometric interaction.

It is clear that the work described here is preliminary, in that significant amounts of antibody are not yet available and monoclonal antibodies have not been produced, so the effects on VEGFR phosphorylation, tumour angiogenesis, or even longer term analysis of the effects on tumour growth are yet to be deduced. However, these preliminary data indicate that VEGF-A $\mathrm{xxx}_{\mathrm{xx}}$-specific antibodies may have considerable benefit both for research and diagnostically in certain patients. Furthermore, VEGF-A $\mathrm{x}_{\mathrm{xxx}}$-specific antibodies may provide the basis for a highly targeted and thus more widely effective therapeutics than current anti-VEGF therapies.

Acknowledgments This work was supported by Cancer Research UK (A14995), the Skin Cancer Research Fund, the MRC (GR0600920), and the National Eye Research Centre. DOB was supported by the British Heart Foundation (BS06/005).

Open Access This article is distributed under the terms of the Creative Commons Attribution License which permits any use, distribution, and reproduction in any medium, provided the original author(s) and the source are credited.

\section{References}

1. Artac RA, McFee RM, Smith RAL, Baltes-Breitwisch MM, Clopton DT, Cupp AS (2009) Neutralization of vascular endothelial growth factor antiangiogenic isoforms is more effective than treatment with proangiogenic isoforms in stimulating vascular development and follicle progression in the perinatal rat ovary. Biol Reprod 81(5):978-988

2. Bates DO, Catalano PJ, Symonds KE, Varey AHR, Ramani P, O'Dwyer PJ, Giantonio BJ, Meropol NJ, Benson AB, Harper SJ (2012) Association between VEGF splice isoforms and progression-free survival in metastatic colorectal cancer patients treated with bevacizumab. Clin Cancer Res 18(22):6384-6391

3. Bates DO, Cui TG, Doughty JM, Winkler M, Sugiono M, Shields JD, Peat D, Gillatt D, Harper SJ (2002) VEGF(165)b, an inhibitory splice variant of vascular endothelial growth factor, is down-regulated in renal cell carcinoma. Cancer Res 62(14): 4123-4131

4. Bates DO, MacMillan PP, Manjaly JG, Qiu Y, Hudson SJ, Bevan HS, Hunter AJ, Soothill PW, Read M, Donaldson LF, Harper SJ (2006) The endogenous anti-angiogenic family of splice variants of VEGF, VEGF(xxx)b, are down-regulated in pre-eclamptic placentae at term. Clin Sci 110(5):575-585

5. Bhattacharjee G, Asplin IR, Wu SM, Gawdi G, Pizzo SV (2000) The conformation-dependent interaction of alpha(2)-macroglobulin with vascular endothelial growth factor-a novel mechanism of alpha(2)-macroglobulin/growth factor binding. J Biol Chem 275(35):26806-26811

6. Bills VL, Varet J, Millar A, Harper SJ, Soothill PW, Bates DO (2009) Failure to up-regulate $\operatorname{VEGF(165)b~in~maternal~plasma~is~}$ a first trimester predictive marker for pre-eclampsia. Clin Sci 116(3-4):265-272

7. Chen J, Li Z, Zhang S, Zhang R, Dassarath M, Wu G (2011) Effects of exogenous $V_{E G F} 165 \mathrm{~b}$ on invasion and migration of human lung adenocarcinoma A549 cells. J Huazhong Univ Sci Technol Med Sci 31(5):619-624

8. Ferrara N, Davis-Smyth T (1997) The biology of vascular endothelial growth factor. Endocr Rev 18(1):4-25

9. Hurwitz $H$ (2004) Integrating the anti-VEGF-A humanized monoclonal antibody bevacizumab with chemotherapy in advanced colorectal cancer. Clin Colorectal Cancer 4(suppl 2): S62-S68

10. Kawamura H, Li X, Harper SJ, Bates DO, Claesson-Welsh L (2008) Vascular endothelial growth factor (VEGF)-A165b is a weak in vitro agonist for VEGF receptor-2 due to lack of coreceptor binding and deficient regulation of kinase activity. Cancer Res 68(12):4683-4692

11. Mitchell P (2011) A systematic review of the efficacy and safety outcomes of anti-VEGF agents used for treating neovascular agerelated macular degeneration: comparison of ranibizumab and bevacizumab. Curr Med Res Opin 27(7):1465-1475

12. Muller YA, Li B, Christinger HW, Wells JA, Cunningham BC, de Vos AM (1997) Vascular endothelial growth factor: crystal structure and functional mapping of the kinase domain receptor binding site. Proc Natl Acad Sci 94(14):7192-7197

13. Nowak DG, Amin EM, Rennel ES, Hoareau-Aveilla C, Gammons M, Damodoran G, Hagiwara M, Harper SJ, Woolard J, Ladomery MR, Bates DO (2010) Regulation of vascular endothelial growth factor (VEGF) splicing from pro-angiogenic to anti-angiogenic isoforms-a novel therapeutic strategy for angiogenesis. J Biol Chem 285(8):5532-5540

14. Oishi A, Yamashiro K, Tsujikawa A, Ooto S, Tamura H, Nakata I, Miyake M, Yoshimura N (2013) Long-term effect of intravitreal injection of anti-VEGF agent for visual acuity and chorioretinal atrophy progression in myopic choroidal neovascularization. Graefe's Arch Clin Exp Ophthalmol 251(1): $1-7$

15. Parker MW, Xu P, Li X, Vander Kooi CW (2012) Structural basis for selective vascular endothelial growth factor-A (VEGF-A) binding to neuropilin-1. J Biol Chem 287(14):11082-11089. doi:10.1074/jbc.M111.331140

16. Perrin RM, Konopatskaya O, Qiu Y, Harper S, Bates DO, Churchill AJ (2005) Diabetic retinopathy is associated with a switch in splicing from anti- to pro-angiogenic isoforms of vascular endothelial growth factor. Diabetologia 48(11):2422-2427

17. Plouet J, Moro F, Bertagnolli S, Coldeboeuf N, Mazarguil H, Clamens S, Bayard F (1997) Extracellular cleavage of the vascular endothelial growth factor 189- amino acid form by urokinase is required for its mitogenic effect. J Biol Chem 272(20):13390-13396

18. Pritchard-Jones RO, Dunn DBA, Qiu Y, Varey AHR, Orlando A, Rigby H, Harper SJ, Bates DO (2007) Expression of $\operatorname{VEGF}(\mathrm{xxx}) \mathrm{b}$, the inhibitory isoforms of VEGF, in malignant melanoma. Br J Cancer 97(2):223-230

19. Qiu Y, Bevan H, Weeraperuma S, Wratting D, Murphy D, Neal CR, Bates DO, Harper SJ (2008) Mammary alveolar development 
during lactation is inhibited by the endogenous antiangiogenic growth factor isoform, VEGF(165)b. FASEB J 22(4):1104-1112

20. Rennel ES, Hamdollah-Zadeh MA, Wheatley ER, Magnussen A, Schuler Y, Kelly SP, Finucane C, Ellison D, Cebe-Suarez S, Ballmer-Hofer K, Mather S, Stewart L, Bates DO, Harper SJ (2008) Recombinant human VEGF(165)b protein is an effective anti-cancer agent in mice. Eur J Cancer 44(13):1883-1894

21. Rennel ES, Waine E, Guan H, Schuler Y, Leenders W, Woolard J, Sugiono M, Gillatt D, Kleinerman ES, Bates DO, Harper SJ (2008) The endogenous anti-angiogenic VEGF isoform, $\operatorname{VEGF}(165) \mathrm{b}$ inhibits human tumour growth in mice. Br J Cancer 98(7):1250-1257

22. Senger DR, Perruzzi CA, Feder J, Dvorak HF (1986) A highly conserved vascular permeability factor secreted by a variety of human and rodent tumor cell lines. Cancer Res 46(11): $5629-5632$

23. Suarez SC, Pieren M, Cariolato L, Arn S, Hoffmann U, Bogucki A, Manlius C, Wood J, Ballmer-Hofer K (2006) A VEGF-A splice variant defective for heparan sulfate and neuropilin-1 binding shows attenuated signaling through VEGFR-2. Cell Mol Life Sci 63(17):2067-2077

24. Varey AHR, Rennel ES, Qiu Y, Bevan HS, Perrin RM, Raffy S, Dixon AR, Paraskeva C, Zaccheo O, Hassan AB, Harper SJ, Bates DO (2008) VEGF(165)b, an antiangiogenic VEGF-A isoform, binds and inhibits bevacizumab treatment in experimental colorectal carcinoma: balance of pro- and antiangiogenic VEGFA isoforms has implications for therapy. Br J Cancer 98(8): 1366-1379

25. Woolard J, Wang W, Bevan H, Qiu Y, Morbidelli L, PritchardJones R, Cui T, Sugiono M, Waine E, Perrin R, Foster R, DigbyBell J, Shields J, Whittles C, Mushens R, Gillatt D, Ziche M, Harper S, Bates D (2004) VEGF165b, an inhibitory vascular endothelial growth factor splice variant: mechanism of action, in vivo effect on angiogenesis and endogenous protein expression. Cancer Res 64(21):7822-7835 